\title{
HUBUNGAN HIPERTENSI DENGAN FAKTOR RISIKO PADA PASIEN PEROKOK YANG BEROBAT DI PUSKESMAS BULILI KOTA PALU
}

\author{
Nita Damayanti ${ }^{1}$, Muh Yaqub Basri ${ }^{1}$, Muh Ali Hi Palanro ${ }^{1}$ \\ ${ }^{1}$ Program Studi Pendidikan Dokter, Fakultas Kedokteran, Universitas Alkhairaat, Jl. Diponegoro Palu \\ 94221, Sulawesi Tengah, Indonesia
}

*Corresponding author: Telp: +62 82292060496, email: nita.unisa@gmail.com

\begin{abstract}
ABSTRAK
Hipertensi menjadi masalah yang besar dan serius di seluruh dunia. Hipertensi menempati urutan ketiga penyakit terbanyak di Sulawesi Tengah pada tahun 2016, hal ini berkaitan erat dengan gaya hidup seperti merokok, diet tinggi lemak dan garam, aktivitas fisik, dan lain-lain yang merupakan faktor risiko hipertensi. Tujuan penelitian untuk mengetahui hubungan profil hipertensi dengan faktor risiko hipertensi pada pasien perokok yang berobat di Puskesmas Bulili Palu. Penelitian ini merupakan penelitian deskriptif dan analitik dengan pendekatan cross sectional study terhadap 80 pasien dewasa yang dilakukan pada bulan Juli sampai September 2019 di Puskesmas Bulili Palu. Pengumpulan data dengan pengukuran tekanan darah dan wawancara menggunakan kuesioner. Hasil penelitian ditemukan profil perokok hipertensi dominan adalah penderita hipertensi derajat 1 yaitu sebanyak 56 orang (70\%); Tidak terdapat hubungan antara profil hipertensi dengan frekuensi merokok $(\mathrm{p}=0,24)$, kebiasaan merokok $(\mathrm{p}=0,448)$, diet tinggi garam $(\mathrm{p}=0,883)$ dan aktivitas fisik $(0,576)$; Terdapat hubungan antara profil hipertensi dengan perilaku diet tinggi lemak $(p=0,026) ; p>0,05$. Kesimpulan pada penelitian ini yaitu diet tinggi lemak merupakan salah satu faktor risiko yang berhubungan dengan profil hipertensi pada pasien perokok yang berobat di Puskesmas Bulili Palu.
\end{abstract}

Kata Kunci: Hipertensi, Perokok, Puskesmas Bulili

\begin{abstract}
Hypertension is a big and serious problem worldwide. Hypertension ranks as the third most common disease in Central Sulawesi in 2016, this is closely related to lifestyles such as smoking, a diet high in fat and salt, physical activity, and others which are risk factors for hypertension. The purpose of the study was to determine the relationship between hypertension profile and hypertension risk factors in smoking patients who were treated at the Bulili Public Health Center, Palu. This research is a descriptive and analytic study with a cross-sectional study approach to 80 adult patients conducted from July to September 2019 at the Bulili Public Health Center in Palu. Data collection by measuring blood pressure and interviews using a questionnaire. The results of the study found that the predominant hypertensive smoker's profile were patients with grade 1 hypertension, as many as 56 people (70\%); There was no correlation between hypertension profile and smoking frequency $(p=0,24)$, smoking habit $(p=0,448)$, high salt diet $(p=0,883)$ and physical activity $(0,576)$; There is a relationship between hypertension profile and high-fat diet behavior ( $p=0.026) ; p>0.05$. This study concludes that a high-fat diet is one of the risk factors associated with hypertension profile in smoking patients who seek treatment at the Bulili Public Health Center in Palu.
\end{abstract}

Keywords: Hypertension, Smoker, Bulili Health Center 


\section{PENDAHULUAN}

Masalah kesehatan dimasyarakat yang dihadapi waktu lalu adalah penyakit menular dengan pesatnya perkembangan penduduk, ekonomi dan teknologi diikuti ula dengan gaya hidup yang berubah. Di wilayah/daerah perkotaan beberapa dekade ini banyak masyarakat sudah mulai terjangkit penyakit tidak menular, dalam pembangunan kesehatan di Indonesia merupakan beban ganda penyakit (double barden), dimana disatu sisi masih ada penyakit tidak menular. Angka kematian penyakit tidak menular meningkat dari 41,7\% pada tahun 1995 menjadi 59,5\% pada tahun 2007. ${ }^{1}$

Hipertensi merupakan masalah yang besar dan serius di seluruh dunia karena hampir 9,4 milyar orang meninggal setiap tahun disebabkan oleh penyakit tersebut. Selain karena prevalensinya yang tinggi dan terus meningkat dari tahun ke tahun, hipertensi juga merupakan penyebab utama timbulnya penyakit kardiovaskuler seperti serangan jantung, gagal jantung, dan stroke. Tekanan darah tinggi (Hipertensi) menjangkiti sekitar $24 \%$ pria dan $20,5 \%$ wanita di seluruh dunia. 2,3,4 Hipertensi adalah keadaan tekanan darah sistolik lebih dari $140 \mathrm{mmHg}$ dan tekanan darah diastolik lebih dari $90 \mathrm{mmHg} .{ }^{5,6}$

Penelitian yang dilakukan di Varanasi, India pada 640 subjek penelitian yang berusia 25-64 tahun diperoleh hasil prevalensi hipertensi adalah 32,9\% (laki-laki: 40,9\%, perempuan: 26,0\%). Kemungkinan lebih tinggi hipertensi ditemukan pada subjek pria, kelompok usia tertua, subjek menikah, subjek status sosial ekonomi atas, subjek buta huruf, dan subjek yang sudah pensiun. Konsumsi tembakau serta alkohol, kelebihan berat badan, obesitas, dan obesitas perut juga dikaitkan dengan hipertensi. ${ }^{7}$

Prevalensi hipertensi di Indonesia cukup tinggi, akibatnya dapat menimbulkan masalah kesehatan masyarakat. Hipertensi merupakan salah satu faktor risiko yang paling berpengaruh terhadap kejadian penyakit jantung dan pembuluh darah. Hipertensi sering tidak menunjukkan gejala dan baru disadari bila telah menyebabkan gangguan organ seperti gangguan fungsi jantung atau stroke. Tidak jarang hipertensi ditemukan secara tidak sengaja pada waktu pemeriksaan kesehatan rutin dengan kelainan lain. ${ }^{1}$

Data riskesdas 2018 mengenai data prevalensi hipertensi di Indonesia pada penduduk umur $\geq 18$ tahun sebesar $34,11 \%$, tertinggi Kalimantan Selatan 44,13\%. Diikuti Jawa Barat 39,60\%, sedangkan Sulawesi Tengah sebesar $29,75 \%$. Meningkat bila dibandingkan pada Riskesdas 2010 yaitu 28,7\%. ${ }^{4}$ Prevalensi hipertensi di kota Palu tahun 2016 sebanyak 1503 kasus yang kemudian meningkat pada pada tahun 2017 sebesar 9400 kasus. Penelusuran data yang dilakukan pada Puskesmas Bulili Palu tahun 2017, hipertensi menjadi penyakit peringkat ke-6 dengan jumlah penderita sebanyak 364 orang dan pada tahun 2018 sebanyak 1358 kasus.

Tingginya prevalensi hipertensi di dunia sehingga membuat banyak penelitian yang terkait dengan faktor risiko hipertensi dalam hal gaya hidup seperti : merokok, makanan tinggi lemak dan garam, kurangnya aktivitas berolahraga, serta ketidak patuhan minum obat antihipertensi yang memicu timbulnya berbagai komplikasi penyakit kardiovaskuler. Diperkirakan angka kematian yang diakibatkan oleh merokok akan meningkat menjadi 8 juta jiwa pada tahun $2030 .^{11,12}$

Indonesia menempati urutan pertama jumlah perokok terbanyak di dunia dengan angka kejadian sebesar $67 \%$, dan untuk kota Palu sendiri menjadi salah satu kota dengan perokok aktif terbanyak di Sulawesi Tengah dengan 2062 jiwa. ${ }^{9,13}$

Tekanan darah merupakan akibat dari kerja pompa jantung yang mengalirkan darah melalui pembuluh darah arteri ke sistem sirkulasi untuk menyalurkan oksigen, nutrisi dan membawa sisa metabolism dari sel. ${ }^{14}$

Adapun pengukuran tekanan darah dapat dilakukan dengan menggunakan alat sphygmomanometer. Menurut American Colllage Of Cardiology dan American Heart of Assosiation tahun 2017, batas normal tekanan darah adalah dibawah $120 \mathrm{mmHg}$ tekanan sistol dan kurang dari $80 \mathrm{mmHg}$ diastole. Seseorang dinyatakan mengidap hipertensi bila tekanan $80 \mathrm{mmHg}$ diastole. Seseorang dinyatakan mengidap hipertensi bila tekanan 
darahnya lebih dari atau sama dengan 130/80 mmHg. ${ }^{15}$

Penelitian ini bertujuan untuk mengetahui hubungan profil hipertensi dengan faktor risiko hipertensi pada pasien perokok yang berobat di Puskesmas Bulili Palu Tahun 2019.

\section{METODE}

Penelitian ini merupakan penelitian kuantitatif yang menggunakan desain deskriptif dan analitik dengan pendekatan cross sectional study yaitu penelitian yang menggambarkan hubungan profil hipertensi dengan faktor risiko hipertensi pada pasien perokok yang berobat di Puskesmas Bulili Palu tahun 2019. Penelitian dilaksanakan pada bulan Juli s/d September 2019 di Puskesmas Bulili Kota Palu.

Populasi dalam penelitian ini adalah penduduk berusia $\geq 18$ tahun yang berobat di Puskesmas Bulili Kota Palu, sedangkan sampel penelitian adalah bagian dari populasi yang memenuhi kriteria inklusi, yaitu pasien terdiagnosa hipertensi dan menyatakan diri sebagai perokok, laki-laki dan/atau perempuan berusia $\geq 18$ tahun serta bersedia menjadi subjek penelitian dan tanpa ada paksaan setelah diberikan penjelasan.

Teknik pengambilan sampel yang digunakan pada penelitian ini adalah dengan menggunakan metode consecutive sampling yaitu mengumpulkan semua sampel setiap hari yang memenuhi kriteria penelitian sampai sampel terpenuhi.

Penentuan besar sampel dari penelitian yang bersifat deskriptif kategorik membutuhkan perhitungan berdasarkan rumus Teknik Slovin dan didapatkan jumlah sampel sebanyak 80 orang.

Analisa data yang digunakan untuk melihat hubungan profil pasien hipertensi perokok berdasarkan kebiasaan merokok, diet tinggi lemak, diet tinggi garam, aktivitas fisik digunakan uji korelasi spearman dengan batas kemaknaan $\alpha=5 \%$.

\section{HASIL DAN PEMBAHASAN}

HASIL

Penelitian ini dilakukan di Puskesmas Bulili Kota Palu tahun 2019 dengan subjek pada penelitian ini diambil dari Populasi
(Penduduk usia $\geq 18$ tahun) yang berobat di Puskesmas Bulili Palu dan memenuhi kriteria sampel sebanyak 80 orang. Pengumpulan data penelitian ini dilakukan dengan cara melakukan pengukuran tekanan darah, pengisian kuesioner kebiasaan merokok, kebiasaan konsumsi makanan tinggi lemak dan garam, serta aktivitas fisik selama seminggu terakhir. Adapun data yang diperoleh terdiri dari tekanan darah sistolik dan diastolik, kebiasaan merokok digolongkan menjadi ringan, sedang dan berat, diet tinggi lemak dan diet tinggi garam yang digolongkan menjadi ringan, sedang dan tinggi.

1. Karakteristik sampel penelitian menurut umur dan jenis kelamin penduduk (usia $\geq 18$ tahun) yang berobat di Puskesmas Bulili Palu tahun 2019.

Tabel 1. dibawah menunjukkan karakteristik dari 80 sampel penduduk berusia $\geq 18$ tahun di Puskesmas Bulili palu:

Tabel 1. Karakteristik Sampel Berdasarkan Usia

\begin{tabular}{ccc}
\hline Usia & Jumlah & $(\%)$ \\
\hline Remaja Akhir (17-25 tahun) & 4 & 5,0 \\
Dewasa Awal (26-35 tahun) & 10 & 12,5 \\
Dewasa Akhir (36-45 tahun) & 12 & 15,0 \\
Lansia Awal (46-55 tahun) & 21 & 26,3 \\
Lansia Akhir (56-65 tahun) & 28 & 35,0 \\
Manula (>65 tahun) & 5 & 6,3 \\
\hline Total & 80 & 100 \\
\hline Tabel 1 diatas & menunjukkan
\end{tabular}

karakteristik sampel penelitian di Puskesmas Bulili Kota Palu tahun 2019 yang berjumlah 80 orang. Dari 80 sampel yang diteliti, diperoleh persentase sampel berusia 17-25 tahun (remaja akhir) sebanyak 4 orang (5\%), sampel berusia 26-35 tahun (dewasa awal) sebanyak 10 orang $(12,5 \%)$, sampel berusia 36-45 tahun (dewasa akhir) sebanyak 12 orang (15\%), berusia 46-55 tahun (lansia awal) sebanyak 21 orang $(26,3 \%)$, berusia 56-65 tahun (lansia akhir) sebanyak 28 orang (35\%), dan sampel berusia $>65$ tahun (manula) sebanyak 5 orang $(6,3 \%)$.

2. Karakteristik sampel berdasarkan jenis kelamin dicantumkan dalam tabel berikut ini: 
Tabel 2. Karakteristik sampel berdasarkan jenis kelamin

\begin{tabular}{lcc}
\hline \multicolumn{1}{c}{ Jenis Kelamin } & Jumlah & $(\%)$ \\
\hline Laki-laki & 47 & 58,8 \\
Perempuan & 33 & 41,3 \\
\hline \multicolumn{1}{c}{ Total } & 80 & 100 \\
\hline
\end{tabular}

Tabel 2 menunjukkan distribusi sampel menurut jenis kelamin digolongkan atas sampel dengan jenis kelamin laki-laki sebanyak 47 orang $(58,8 \%)$, sedangkan yang berjenis kelamin perempuan sebanyak 33 orang $(41,3 \%)$.

3. Profil hipertensi pada pasien perokok yang berobat di Puskesmas Bulili Kota Palu tahun 2019.

Tabel 3. Profil hipertensi pasien perokok berdasarkan klasifikasi hipertensi menurut JNC 7

\begin{tabular}{ccc}
\hline Hipertensi & Jumlah & $(\%)$ \\
\hline Hipertensi Derajat I & 56 & 70,0 \\
Hipertensi Derajat II & 24 & 30,0 \\
\hline Total & 80 & 100
\end{tabular}

Tabel 3 di atas menunjukkan distribusi 80 subjek penelitian yang menderita Hipertensi derajat I adalah sebanyak 56 orang (70\%) lebih besar daripada subjek yang menderita Hipertensi derajat II yaitu senyak 24 orang $(30 \%)$.

4. Distribusi karakteristik perilaku pada pasien perokok berdasarkan frekuensi merokok yang berobat di Puskesmas Bulili Kota Palu tahun 2019.

Tabel 4. Distribusi karakteristik perilaku pada pasien perokok berdasarkan frekuensi merokok

\begin{tabular}{lcc}
\hline Frekuensi Merokok & Jumlah & $(\%)$ \\
\hline Perokok Ringan & 21 & 26,3 \\
Perokok Sedang & 52 & 65 \\
Perokok Berat & 7 & 8,8 \\
\hline \multicolumn{1}{c}{ Total } & 80 & 100 \\
\hline Tabel 4 & menunjukkan & bahwa
\end{tabular}

responden yang merokok antara 1-10 batang perhari (perokok ringan) berjumlah 21 orang $(26,3 \%)$, responden yang merokok 11-20 batang perhari (perokok sedang) berjumlah 52 orang $(65 \%)$, dan responden yang merokok
$>20$ batang perhari (perokok berat) berjumlah 7 orang $(8,8 \%)$.

5. Distribusi karakteristik perilaku pada pasien perokok berdasarkan lama merokok yang berobat di Puskesmas Bulili Kota Palu tahun 2019.

Tabel 5. Distribusi karakteristik perilaku pada pasien perokok berdasarkan lama merokok

\begin{tabular}{ccc}
\hline \multicolumn{1}{c}{ Lama Merokok } & Jumlah & $(\%)$ \\
\hline Perokok Pemula & 7 & 8,8 \\
Perokok Menengah & 27 & 33,8 \\
Perokok Lama & 46 & 57,5 \\
\hline \multicolumn{1}{c}{ Total } & 80 & 100
\end{tabular}

Tabel 5 menunjukkan data terkait distribusi responden yang berobat di Puskesmas Bulili Palu tahun 2019 berdasarkan lama merokok. Adapun responden yang merokok < 5 tahun (perokok pemula) berjumlah 7 orang $(8,8 \%)$, responden yang selama 5-10 tahun (perokok menengah) berjumlah 27 orang $(33,8 \%)$, sedangkan responden yang sudah merokok selama $>10$ (perokok lama) berjumlah 46 orang $(57,5 \%)$.

6. Distribusi karakteristik perilaku pada pasien perokok berdasarkan diet tinggi lemak yang berobat di Puskesmas Bulili Kota Palu tahun 2019

Tabel 6. Karakteristik sampel berdasarkan diet tinggi lemak

\begin{tabular}{lcc}
\hline Diet Tinggi Lemak & Jumlah & $(\%)$ \\
\hline Ringan & 21 & 26,3 \\
Sedang & 40 & 50 \\
Berat & 19 & 23,8 \\
Sangat Berat & 0 & 0,0 \\
\hline \multicolumn{1}{c}{ Total } & 80 & 100 \\
\hline
\end{tabular}

Tabel 6 tersebut dapat diketahui responden dengan diet lemak tinggi yang tergolong katerogi ringan (1-2 kali perminggu) berjumlah 21 orang $(26,3 \%)$, responden dengan kategori sedang (3-6 kali perminggu) berjumlah 40 orang $(50 \%)$, dan responden dengan kategori berat (7 kali perminggu) berjumlah 19 orang $(23,8 \%)$, sementara responden dengan diet tinggi lemak kategorik sangat berat (lebih dari 1 kali dalam sehari) tidak ada. 
7. Distribusi karakteristik perilaku pasien perokok berdasarkan diet tinggi garam yang berobat di Puskesmas Bulili Kota Palu tahun 2019.

Tabel 7. Karakteristik sampel berdasarkan diet tinggi garam

\begin{tabular}{|c|c|c|}
\hline Diet Tinggi Garam & Jumlah & $(\%)$ \\
\hline Ringan & 16 & 20 \\
\hline Sedang & 53 & 66,3 \\
\hline Berat & 9 & 11,3 \\
\hline Sangat Berat & 2 & 2,5 \\
\hline Total & 80 & 100 \\
\hline
\end{tabular}

Tabel 7 berikut menunjukkan bahwa responden dengan diet tinggi garam kategori ringan (1-2 kali perminggu) berjumlah 16 orang $(20 \%)$, responden dengan kateori sedang (3-6 kali perminggu) berjumlah 53 orang $(66,3 \%)$, responden dengan kategori berat (7 kali perminggu), dan responden dengan kategori diet tinggi garam yang tergolong sangat berat (lebih dari 1 kali dalam sehari) berjumlah 2 orang $(2,5 \%)$.

8. Distribusi karakteristik perilaku pasien perokok berdasarkan aktivitas olahraga yang berobat di Puskesmas Bulili Kota Palu tahun 2019

Tabel 8. Karakteristik sampel berdasarkan aktivitas fisik

\begin{tabular}{ccc} 
Aktifitas Olahraga & Jumlah & $(\%)$ \\
\hline Aktivitas Ringan & 53 & 66,3 \\
Aktivitas Sedang & 27 & 33,8 \\
Aktivitas Berat & 0 & 0,0 \\
\hline \multicolumn{1}{c}{ Total } & 80 & 100
\end{tabular}

Tabel 8 diatas menunjukkan bahwa responden dengan aktifitas olahraga yang tergolong ringan (jarang atau tidak pernah berolahraga) sebanyak 53 orang $(66,3 \%)$, responden dengan aktivitas fisik sedang (selama kurang dari 30 menit perhari atau kurang dari 3 hari perminggu), dan responden dengan aktivitas fisik yang tergolong berat (selama lebih dari/sama dengan 30 menit perhari atau lebih dari/sama dengan 3 hari perminggu).

9. Hubungan profil hipertensi dengan
Tabel 9. Hubungan profil hipertensi dengan frekuensi merokok

\begin{tabular}{lccc}
\hline \multirow{2}{*}{$\begin{array}{c}\text { Frekuensi } \\
\text { merokok }\end{array}$} & \multicolumn{2}{c}{ Profil Hipertensi } & \\
\cline { 2 - 3 } & $\begin{array}{c}\text { Hipertensi } \\
\text { Gr. 1 }\end{array}$ & $\begin{array}{c}\text { Hipertensi } \\
\text { Gr. 2 }\end{array}$ & \multirow{2}{*}{ Total } \\
\cline { 2 - 3 } & $\mathrm{n}(\%)$ & $\mathrm{n}(\%)$ & \\
\hline Ringan & 13 & $8(38,1 \%)$ & 21 \\
& $(61,9 \%)$ & $(100,0 \%)$ \\
\hline Sedang & 37 & 15 & 52 \\
& $(71,2 \%)$ & $(28,8 \%)$ & $(100,0 \%)$ \\
\hline Berat & 6 & 1 & 7 \\
& $(85,7 \%)$ & $(14,3 \%)$ & $(100,0 \%)$ \\
\hline Total & 56 & 24 & 80 \\
& $(70,0 \%)$ & $(30,0 \%)$ & $(100,0 \%)$ \\
\hline
\end{tabular}

Ket. Korelasi spearman : $r=-1,33$ dan $\mathrm{p}=0,24$ Tabel 9 menunjukkan bahwa tidak ditemukannya hubungan bermakna antara frekuensi merokok dan derajat tekanan darah pada responden yang menderita hipertensi di Puskesmas Bulili Palu. Hasil korelasi spearman menunjukkan korelasi negative yaitu nilai $r=-1,33$ dan nilai $p=0,24(p>0,05)$.

10. Hubungan profil hipertensi dengan lama merokok.

Tabel 10. Hubungan profil hipertensi dengan lama merokok.

\begin{tabular}{lccc}
\hline \multirow{2}{*}{$\begin{array}{c}\text { Lama } \\
\text { merokok }\end{array}$} & \multicolumn{2}{c}{ Profil Hipertensi } & \\
\cline { 2 - 3 } & $\begin{array}{c}\text { Hipertensi } \\
\text { Gr. 1 }\end{array}$ & $\begin{array}{c}\text { Hipertensi } \\
\text { Gr. 2 }\end{array}$ & \multirow{2}{*}{ Total } \\
\cline { 2 - 3 } & $\mathrm{n}(\%)$ & $\mathrm{n}(\%)$ & \\
\hline Ringan & 5 & 2 & 7 \\
& $(71,4 \%)$ & $(28,6 \%)$ & $(100,0 \%)$ \\
\hline Sedang & 17 & 10 & 27 \\
& $(63,0 \%)$ & $(37,0 \%)$ & $(100,0 \%)$ \\
\hline Berat & 34 & 12 & 46 \\
& $(73,9 \%)$ & $(26,1 \%)$ & $(100,0 \%)$ \\
\hline Total & 56 & 24 & 80 \\
& $(70,0 \%)$ & $(30,0 \%)$ & $(100,0 \%)$ \\
\hline
\end{tabular}

Ket. Korelasi spearman : $r=-0,86$ dan $p=0,448$

Tabel 10 menunjukkan bahwa tidak ditemukannya hubungan bermakna antara lama merokok dan derajat tekanan darah pada responden yang menderita hipertensi di Puskesmas Bulili Palu. Hasil korelasi spearman menunjukkan korelasi negatif yaitu nilai $\mathrm{r}=-0,86$ dan nilai $\mathrm{p}=0,448(\mathrm{p}>0,05)$.

\section{Hubungan profil hipertensi dengan diet tinggi lemak.}


Tabel 11. Hubungan profil hipertensi dengan diet tinggi lemak

\begin{tabular}{cccc}
\hline \multirow{2}{*}{$\begin{array}{c}\text { Diet } \\
\text { tinggi } \\
\text { lemak }\end{array}$} & \multicolumn{2}{c}{ Profil Hipertensi } & \\
\cline { 2 - 3 } & $\begin{array}{c}\text { Hipertensi } \\
\text { Gr. 1 }\end{array}$ & $\begin{array}{c}\text { Hipertensi } \\
\text { Gr. 2 }\end{array}$ & \multirow{2}{*}{ Total } \\
\cline { 2 - 3 } & $\mathrm{n}(\%)$ & $\mathrm{n}(\%)$ & \\
\hline Ringan & 10 & 11 & 21 \\
& $(47,6 \%)$ & $(52,4 \%)$ & $(100,0 \%)$ \\
\hline Sedang & 31 & 9 & 40 \\
& $(77,5 \%)$ & $(22,5 \%)$ & $(100,0 \%)$ \\
\hline Berat & 15 & 4 & 19 \\
& $(78,9 \%)$ & $(21,1 \%)$ & $(100,0 \%)$ \\
\hline Total & 56 & 24 & 80 \\
& $(70,0 \%)$ & $(30,0 \%)$ & $(100,0 \%)$ \\
\hline
\end{tabular}

Ket. Korelasi spearman: $r=-0,249$ dan $p=0,026$

Tabel 11 menunjukkan bahwa ada hubungan bermakna antara diet tinggi lemak dan derajat tekanan darah pada responden yang menderita hipertensi di Puskesmas Bulili Palu. Hasil korelasi spearman menunjukkan korelasi negatif yaitu nilai $r=-0,249$ dan nilai $\mathrm{p}=0,026(\mathrm{p}<0,05)$.

\section{Hubungan profil hipertensi dengan diet tinggi garam.}

Tabel 12. Hubungan profil hipertensi dengan diet tinggi garam.

\begin{tabular}{|c|c|c|c|}
\hline \multirow{3}{*}{$\begin{array}{l}\text { Diet } \\
\text { tinggi } \\
\text { garam }\end{array}$} & \multicolumn{2}{|c|}{ Profil Hipertensi } & \multirow{3}{*}{ Total } \\
\hline & $\begin{array}{l}\text { Hipertensi } \\
\text { Gr. } 1\end{array}$ & $\begin{array}{l}\text { Hipertensi } \\
\text { Gr. } 2\end{array}$ & \\
\hline & $\mathrm{n}(\%)$ & $\mathrm{n}(\%)$ & \\
\hline Ringan & $\begin{array}{c}11 \\
(68,8 \%)\end{array}$ & $\begin{array}{c}5 \\
(31,3 \%)\end{array}$ & $\begin{array}{c}16 \\
(100,0 \%)\end{array}$ \\
\hline Sedang & $\begin{array}{c}38 \\
(71,7 \%)\end{array}$ & $\begin{array}{c}15 \\
(28,3 \%)\end{array}$ & $\begin{array}{c}53 \\
(100,0 \%)\end{array}$ \\
\hline Berat & $\begin{array}{c}6 \\
(66,7 \%)\end{array}$ & $\begin{array}{c}3 \\
(33,3 \%)\end{array}$ & $\begin{array}{c}9 \\
(100,0 \%)\end{array}$ \\
\hline $\begin{array}{l}\text { Sangat } \\
\text { Berat }\end{array}$ & $\begin{array}{c}1 \\
(50,0 \%)\end{array}$ & $\begin{array}{c}1 \\
(50,0 \%)\end{array}$ & $\begin{array}{c}2 \\
(100,0 \%)\end{array}$ \\
\hline Total & $\begin{array}{c}56 \\
(70,0 \%) \\
\end{array}$ & $\begin{array}{c}24 \\
(30,0 \%)\end{array}$ & $\begin{array}{c}80 \\
(100,0 \%)\end{array}$ \\
\hline
\end{tabular}

Ket. Korelasi spearman : $r=0,024$ dan $p=0,833$

Tabel 12 menunjukkan bahwa tidak ada hubungan bermakna antara diet tinggi garam dan derajat tekanan darah pada responden yang menderita hipertensi di Puskesmas Bulili Palu. Hasil korelasi spearman menunjukkan korelasi positif yaitu nilai $r=0,024$ dan nilai $p=0,833(p>0,05)$.
13. Hubungan profil hipertensi dengan aktivitas fisik.

Tabel 13. Hubungan profil hipertensi dengan aktivitas fisik.

\begin{tabular}{cccc}
\hline \multirow{2}{*}{$\begin{array}{c}\text { Aktivitas } \\
\text { fisik }\end{array}$} & \multicolumn{2}{c}{ Profil Hipertensi } & \\
\cline { 2 - 3 } & $\begin{array}{c}\text { Hipertensi } \\
\text { Gr. 1 }\end{array}$ & $\begin{array}{c}\text { Hipertensi } \\
\text { Gr. 2 }\end{array}$ & \multirow{2}{*}{ Total } \\
\cline { 2 - 3 } Ringan & $\begin{array}{c}\mathrm{n}(\%) \\
(67,9 \%)\end{array}$ & $\begin{array}{c}\mathrm{n}(\%) \\
(32,1 \%)\end{array}$ & $\begin{array}{c}53 \\
(100,0 \%)\end{array}$ \\
\hline \multirow{2}{*}{ Sedang } & 20 & $7(25,9 \%)$ & $\begin{array}{c}27 \\
(100,0 \%)\end{array}$ \\
\hline \multirow{2}{*}{ Total } & 56 & 24 & 80 \\
& $(70,0 \%)$ & $(30,0 \%)$ & $(100,0 \%)$ \\
\hline
\end{tabular}

Ket. Korelasi spearman : $r=-0,63$ dan $p=0,576$

Tabel 13 menunjukkan bahwa tidak ada hubungan bermakna antara aktivitas fisik dan derajat tekanan darah pada responden yang menderita hipertensi di Puskesmas Bulili Palu. Hasil korelasi spearman menunjukkan korelasi negatif yaitu nilai $r=-0,63$ dan nilai $\mathrm{p}=0,576(\mathrm{p}>0,05)$.

\section{PEMBAHASAN}

1. Karakteristik demografi pasien perokok yang menderita hipertensi berdasarkan usia dan jenis kelamin yang berobat di Puskesmas Bulili Kota Palu tahun 2019.

Adapun karakteristik sampel penelitian berdasarkan usia pada penelitian ini ditemukan sebanyak 80 orang responden penelitian terdapat 4 orang $(5,0 \%)$ tergolong remaja akhir (17-25 tahun), sebanyak 10 orang $(12,5 \%)$ tergolong dewasa awal (26-35 tahun), sebanyak 12 orang $(15,0 \%)$ tergolong dewasa akhir (36-45 tahun), sebanyak 21 orang (26,3\%) tergolong lansia awal (46-55 tahun), sebanyak 28 orang $(35,0 \%)$ tergolong lansia akhir (56-65 tahun), serta 5 orang $(6,3 \%)$ sudah tergolong manula ( $\geq 65$ rahun). Kebanyakan dari reponden penelitian berjenis kelamin laki-laki yaitu 47 orang $(58,8 \%)$ sementara perempuan sebanyak 33 orang $(41,3 \%)$. Hasil dari penelitian tersebut sejalan dengan penelitian yang dilakukan oleh Mochammad Choirul H (2013), yang melakukan pengkajian terhadap karakteristik perokok di Indonesia menurut data riskesdas dari tahun 2007-2010 yang menemukan karakteristik perokok di Indonesia berdasarkan kelompok usia terbanyak adalah pada kelompok usia 45-54 tahun (lansia awal), hasil 
terebut cenderung mengalami peningkatan dari tahun 2007 hingga tahun 2010 pada kelompok usia 55-64 tahun (lansia akhir) yakni dari 38\% menjadi $38,2 \%$. Berdasarkan pengkajian ini pula ditemukan karakteristik reponden perokok dari tahun 2007-2010 menurut jenis kelamin ditemukan lebih dominan pada responden laki-laki yaitu dari $55,7 \%$ menjadi $65,9 \%$ di tahun $2010 .^{16}$

Sejalan dengan pengkajian tersebut, pada penelitian yang dilakukan oleh Eric Untario (2017) ditemukan karakteristik perokok yang menderita hipertensi pada masyarakat kelurahan Tamanurung, Kecamatan Mariso Kota Makassar kebanyakan pada usia 41-50 tahun atau yang tergolong lansia awal sebanyak 32 orang (31,37\%), namun pada penelitianya didapatkan distribusi karakteristik perokok berdasarkan jenis kelamin yang justru berbeda degan penelitian ini, yaitu dengan ditemukannya kebanyakan dari responden penelitian justru berjenis kelamin perempuan yang berjumlah 55 orang $(53,9 \%)$ dan laki-laki berjumlah 47 orang $(46,1 \%) .{ }^{17}$

Sebagai kesimpulan dalam penelitian ini, dapat diketahui bahwa perokok yang terdiagnosa hipertensi di Puskemas Bulili kota Palu tahun 2019 dominan berusia $\geq 40$ tahun atau tergolong lansia awal-akhir dan kebanyakan dari mereka berjenis kelamin lakilaki. Hal ini mungkin saja dikarenakan masih banyak dari masyarakat yang berobat di Puskesmas Bulili belum mendapatkan edukasi kesehatan tentang bahaya dari mengkonsumsi rokok serta perilaku gaya hidup yang dapat menyebabkan timbulnya hipertensi serta komplikasi yang diakibatkannya.

2. Hubungan profil hipertensi dengan frekuensi merokok pada pasien perokok yang berobat di Puskesmas Bulili Kota Palu tahun 2019.

Berdasarkan hasil analisis dengan menggunakan uji korelasi Spearman, dalam penelitian ini didapatkan hasil bahwa tidak ada hubungan yang bermakna antara profil hipertensi dengan frekuensi merokok pada pasien perokok yang berobat di Puskesmas Bulili Kota Palu yang dibuktikan dengan nilai $\mathrm{p}=0,24(\mathrm{p}>0,05)$.
Hasil ini sejalan dengan penelitian yang dilakukan oleh Irhamsyah A. dan Indriani (2018) melalui uji korelasi spearman, yang juga tidak ditemukan hubungan bermakna antara kebiasaan merokok dengan tekanan darah dimana nilai $\mathrm{p}=0,325$ $(\mathrm{p}>0,05) .{ }^{18}$ Hal yang sama juga didapatkan pada penelitian yang dilakukan oleh Anggraeny R dkk (2013) di wilayah kerja Puskesmas pattingalloang Makassar dengan sampel penduduk dewasa yang tidak ditemukannya hubungan bermakna antara kebiasaan merokok dengan tekanan darah. ${ }^{19}$

Dengan begitu dapat disimpulkan bahwa kebiasaan merokok berdasarkan frekuensi merokok pada penderita hipertensi yang berobat di Puskesmas Bulili kota Palu bukan menjadi factor risiko dari hipertensi yang didapatkannya, melainkan perlu dilakukan pengkajian lain terhadap pola perilaku gaya hidup masyarakat di wilayah kerja Puskesmas Bulili yang bisa menjadi factor risiko yang berpotensi menyebabkan timbulnya hipertensi seperti diet, stress, ataupun faktor usia.

\section{Hubungan profil hipertensi dengan lama} merokok pada pasien perokok yang berobat di Puskesmas Bulili Kota Palu tahun 2019.

Dalam penelitian yang dilakukan oleh Wahyudi I (2014) yang mendapatkan hasil bahwa semakin lama seseorang merokok maka akan semakin berdampak terhadap peningkatan tekanan darah yang dimilikinya, kandungan zat kimia dalam rokok memiliki dose-respone effect sehingga semakin dini seseorang mengkonsumsi rokok maka akan semakin besar pengaruhnya dalam waktu yang lama, oleh karena semakin banyaknya zat toksin yang menumpuk sehingga pada kurun waktu yang lama akan memperlihatkan dampak dari merokok yang berbahaya seperti penyakit stroke, infakr miokardium, impotensi, kanker, dll. ${ }^{20}$

Terkait dengan lama merokok juga dibahas dalam penelitian yang dilakukan oleh Tesa K.,A.N pada tahun 2012 yang mengatakan bahwa kelainan tekanan darah pada perokok disebabkan karena faktor generative, dimana seiring bertambahnya usia (>40 tahun) maka dinding arteri akan 
mengalami penebalan oleh karena penumpukan zat kalogen yang menyebabkan penyempitan dinding pembuluh darah dan mejadi kaku. Zat yang terkandung dalam rokok dapat memicu plak atherosclerosis, disfungsi endotel, dsb. ${ }^{21}$

Penelitian tersebut diatas didukung dengan penelitian yang telah dilakukan oleh Hasrin M, dkk (2012) yang mendapati hasil bahwa dari 57,3\% kelompok kasus yang merokok $\geq 20$ batang perhari dan lama merokok $>10$ tahun dapat beresiko 2,32 kali menderita hipertensi, namun pada temuannya tidak dijelaskan derajat hipertensi yang diderita 82 orang pada kelompok kasus. ${ }^{22}$

Berbeda dengan penelitian sebelumnya, dalam penelitian ini dilakukan analisis hubungan antara lama merokok dengan derajat hipertensi yang diderita oleh responden melalui uji korelasi spearman, didapati hasil nilai $\mathrm{p}=0,448 \quad(\mathrm{p}>0,05)$ yang menandakan bahwa tidak adanya hubungan bermakna antara lama merokok dengan derajat hipertensi pada responden yang berobat di Puskesmas Bulili Palu. Hal ini kemungkinan disebabkan karena kebanyakan dari frekuensi merokok pada pasien perokok di Puskesmas Bulili Palu yang tergolong sedang, sehingga diperlukan pengkajian seccara mendalam adanya faktor risiko lain yang menjelaskan hubungan derajat hipertensi pasien perokok dengan perilaku merokok yang dimilikinya.

4. Hubungan profil hipertensi dengan diet tinggi lemak pada pasien perokok yang berobat di Puskesmas Bulili Kota Palu tahun 2019.

Pada penelitian yang dilakukan oleh Wahyudi I (2014), dikatakn bahwa konsumsi pangan tinggi lemak seperti jeroan (usus, hati, babat, lidah, jantung, otak dan paru) banyak mengandung asam lemak jenuh (saturated fatty acid/sfa), dimana kandungan kolesterol dalam jeroan 4-15 kali lebih tinggi dibandingkan dengan daging. Secara umum, asam lemak jenuh cenderung meningkatkan kolesterol darah. Lemak jenuh terutama berasal dari minyak kelapa, santan dan semua minyak lin seperti minyak jagung, minyak kedelai yang mendaoatkan pemanasan tinggi atau dipanaskan secara berulang dapat berdampak pada peningkatan kadar LDL dalam darah. ${ }^{20}$

$$
\text { Obesitas dapat menyebabkan }
$$

hipertensu dan penyakit kardiovaskular dikarenakan diet tinggi lemak dan karbohidrat dapat meningkatkan konsentrasi norepinefrin di jaringan perifer. Hal ini menyebabkan stimulasi reseptor al dan b-adrenergik dapat meningkatkan aktivitas saraf simpatis. Apabila terjadi dalam jangka yang waktu lama akan meningkatkan tekanan arteri serta vasokonstriki perifer dan menyebabkan peningkatan tekanan darah. Selain hipertensi, timbunan adipose abdomen juga berperan dalam pathogenesis penyakit jantung coroner dan stroke. ${ }^{23}$

Pada analisis statistik melalui uji korelasi spearman didapati hasil yang menunjukkan adanya hubungan bermakna antara diet tinggi lemak dan derajat hipertensi yang diderita responden, dimana hasil dari uji korelasi spearman diperoleh nilai $\mathrm{p}=0,026$ $(\mathrm{p}<0,05)$ yang berarti, responden dengan diet tinggi lemak memiliki pengaruh terhadap derajat hipertensi yang dideritanya.

Hasil tersebut senada dengan penelitian yang dilakukan oleh Adnyani P.P dan Sudana I.W (2014) yang menemukan bahwa terdapat hubungan positif yang mempengaruhi derajat hipertensi pada perokok dengan konsumsi lemak berlebih yang dinilai dari lingkar pinggang, sehingga diperoleh nilai $r=0,664$ dan nilai $p=0,000$. Hal ini tersebut berarti dari 40 orang penderita hipertensi terdapat $65 \%$ diantaranya yang menderita hipertensi derajat 1 dan $35 \%$ selebihnya penderita hipertensi derajat 2 erat dikaitkan dengan perilaku diet tinggi lemak oleh responden. ${ }^{24}$ Penelitian ini juga sejalan dengan penelitian yang dilakukan oleh Aris, S (2007) yang menemukan adanya hubungan bermakna antara peningkatan derajat hipertensi pada masyarakat Kabupaten Karanganyar dengan kebiasaan mengkonsumsi lemak jenuh $\geq 3$ kali per minggu dimana nilai $r=7,72$ dan nilai $p=0,024$. Sehingga disimpulkan dalam penelitiannya bahwa masyarakat yang memiliki perilaku sering mengkonsumsi lemak jenuh dapat berisiko 7,72 kali memiliki peningkatan tekanan darah. $^{25}$

Jadi dapat disimpulkan dalam penelitian ini bahwa perilaku mengkonsumsi 
makanan tinggi lemak pada pasien perokok yang berobat di Puskesmas Bulili Kota palu menjadi faktor risiko yang meningkatkan derajat hipertensi yang dimilikinya, sehingga perlu dilakukan penyuluhan kepada masyarakat di wilayah kerja ataupun yang berobat di Puskesmas Bulili palu terkait pentingnya mengatur pola perilaku mengkonsumsi makanan tinggi lemak.

5. Hubungan profil hipertensi dengan diet tinggi garam pada pasien perokok yang berobat di Puskesmas Bulili Kota Palu tahun 2019.

Berdasarkan penelitian yang dilakukan oleh Wahyudi I (2014), dijelaskan terkait reabsorbsi natrium oleh tubulus ginjal dapat meningkat pada penderita dengan hipertensi primer yang terjadi karena stimulus beberapa pengangkut natrium yang terletak di membrane basolateral dan menyediakan energy untuk transport tersebut. Hal lain yang menyebabkan terjadinya peningkatan kadar natrium adalah karena zat endogen yang disebut digitalis-like faktor yang identic dengan oubain atau juga dikenal dengan stereoisomer dari oubain, dilepaskan oleh kelenjar adrenal sebagai respon terhadap asupan natrium yang tinggi. Pada penderita hipertensi primer ditemukan kadar digitalislike faktor yang tinggi dalam plasma. Hal ini dapat mengakibatkan retensi natrium dengan cara meningkatkan aktifitas pompa natrium ginjal. $^{20}$

Dalam reviewe penelitian yang dilakukan oleh Nuraini B (2015) mengenai pola asupan garam sebagaimana yang dianjurkan oleh badan kesehatan dunia yaitu WHO (World Health Organization), merekomendasikan pola konsumsi garam yang dapat mengurangi risiko hipertensi adalah tidak melebihi $100 \mathrm{mmol}$ (sekitar 2,4-6 gram garam) perhari. Konsumsi natrium yang berlebih dapat menyebabkan konsentrasi natrium di dalam cairan ekstrakuler meningkat sehingga untuk menormalkannya, cairan intraseluler ditarik keluar. Meningkatkan volume cairan ekstraseluler menyebabkan meningkatnya volume darah, sehingga dapat berdampak kepada timbulnya hipertensi. ${ }^{26,27}$

Senada dengan penelitian tersebut, analisis bivariate dalam penelitian yang dilakukan oleh Hasrin M, dkk (2012) di Puskesmas Kecamatan Bangkala kabupaten Jeneponto terkait dengan konsumsi garam terhadap kejadian hipertensi, didapat hasil $\mathrm{OR}=4,16$ yang berarti dari $52,4 \%$ responden yang mengkonsumsi makanan tinggi garam melebihi nilai rata-rata beresiko 4,16 kali menderita hipertensi. ${ }^{22}$

Walaupun demikian, pengaruh diet tinggi garam dan derajat hipertensi mesti dilakukan pengkajian lebih mendalam lagi oleh karena pada analisia statistic melalui uji korelasi spearman menunjukkan hasil dengan nilai $p=0,883 \quad(p>0,05)$ yang menandakan bahwa tidak adanya hubungan bermakna antara diet tinggi garam dan derajat hipertensi yang diderita oleh responden dalam penelitian ini. Senada dengan penelitian ini, yang dilakukan oleh Ekowati R, dkk (2009) yang juga tidak menemukan adanya hubungan bermakna pada perilaku konsumsi garam (makanan asin) dengan kejadian hipertensi pada perilaku konsumsi garam dengan kejadian hipertensi pada masyarakat Indonesia melalui analisis data Riskesda tahun 2007 yang dibuktikan dengan nilai $\mathrm{OR}=1,00{ }^{28}$

Sehingga dalam penelitian ini dapat disimpulkan bahwa perokok yang berobat di Puskesmas Bulili dengan pola perilaku konsumsi makanan tinggi garam tidak terpengaruh terhadap derajat hipertensi yang dimilikinya. Namun perlu dilakukan pengkajian lebih mendalam antara hubungan peningkatan derajat hipertensi dan perilaku konsumsi makanan tinggi garam pada penelitian selanjutnya.

\section{Hubungan profil hipertensi dengan} aktivitas fisik pada pasien perokok yang berobat di Puskesmas Bulili Kota Palu tahun 2019.

Dalam penelitian yang dilakukan Irhamsyah A dan Indriani (2018), melakukan aktivitas fisik dengan intensitas sedang hingga tinggi dapat mempengaruhi tekanan darah melalui beberapa mekanisme yaitu dengan meningkatkan aktivitas sistem saraf simpatis yang diyakini sebagai penyebab tekanan darah tinggi esensial. Dalam penelitiannya dikatakan bahwa mereka dengan peningkatan kadar hormone noradrenalin menunjukkan penurunan tekanan darah yang berasal dari 
tekanan darah ke otak, meningkatkan pelepasan hormone growth factor atau faktor pertumbuhan dari otot rangka ke pembuluh darah, berperan dalam proses neurogenesis (perkembangan sel saraf baru atau neuron), menstimulasi angiogenesis (pembentukan sel darah baru), mempengaruhi proliferasi sel endotel dalam bentuk lapisan dalam pembuluh darah dan mempengaruhi permeabilitas endotel sel membran. ${ }^{18}$

Kurangnya aktivitas fisik juga dijelaskan oleh Nuraini B (2015) yang menyatakan bahwa risiko terjadinya tekanan darah tinggi dapat terjadi menjadi lebih berat karena faktor tersebut karena kondisi tersebut dapat menyebabkan seseorang menjadi gemuk. Orang-orang yang tidak aktif cenderung mempunyai detak jantung lebih ceoat dan otot jantung mereka harus bekerja lebih keras pada setiap kontraksi semakin keras dan sering jantung harus memompa, maka semakin besar pula kekuatan yang mendesak arteri sehingga menaikkan darah. ${ }^{27}$

Dari penelitian yang dilakukan oleh Irhamsyah A dan Indriani (2018) didapatkan hasil proporsi aktivitas fisik dan tekanan darah memiliki hubungan positif dengan nilai $\mathrm{p}=0,000 \quad(\mathrm{p}<0,05)$ dan $\mathrm{r}=-0,313$ yang menandakan terdapat pengaruh aktivitas fisik masyarakat di wilayah kerja Puskesmas Tipo dengan kejadian hipertensi, namun berbeda halnya dengan penelitian tersebut. Dalam penelitian ini tidak didapatkan adanya hubungan positif antara aktivitas fisik responden perokok dengan derajat hipertensi yang dideritanya, hal ini dibuktikan melalui analisa statistik uji korelasi spearman yang diperoleh nilai $\mathrm{p}=0,576 \quad(\mathrm{p}>0,05)$ dan $\mathrm{r}=-0,63{ }^{18}$

Hasil pada penelitian ini sejalan dengan penelitian yang dilakukan oleh Silviana T, dkk (2019) pada Survey IFLS (Indonesia Family Life Surve) yang juga tidak menemukan hubungan bermakna antara aktivitas fisik dengan derajat hipertensi pada masyarakat, dibuktikan dengan nilai $\mathrm{p}=0,457$ ( $>>0,05)$.

Sehingga dapat disimpulkan dalam penelitian ini bahwa, hipertensi pasien perokok yang berobat di Puskesmas Bulili Palu tidak dipengaruhi oleh perilaku aktivitas fisik dalam kesehariannya, namun perlu dilakukannya penelitian labih lanjut mengenai hal tersebut oleh karena dalam penelitian ini memiliki keterbatasan waktu yang menyebabkan tidak dapat mengikuti pola perilaku aktifitas fisik responden selama seminggu terakhir sehingga hanya melakukan pengambilan data sewaktu terhadap responden penelitian. ${ }^{29}$

\section{KESIMPULAN}

Berdasarkan hasil penelitian yang dilakukan pada 80 penduduk dewasa yang berobat di Puskesmas Bulili Kota Palu didapatkan kesimpulan:

1. Tidak ditemukan adanya hubungan antara profil hipertensi dengan kebiasaan merokok, diet tinggi garam, dan aktivitas fisik penderita hipertensi perokok yang berobat di Puskesmas Bulili Kota Palu tahun 2019.

2. Terdapat hubungan antara profil hipertensi dengan perilaku diet tinggi lemak enderita hipertensi perokok yang berobat di Puskesmas Bulili Kota Palu tahun 2019.

\section{DAFTAR PUSTAKA}

1. Departemen Kesehatan RI. Hasil Riset Kesehatan Dasar. Badan Penelitian dan Pengembangan Kesehatan; 2010.

2. WHO. High Blood Pressure Global dan Regional Overview. Published 2013. http://www.searo.who.int/entity/world_hea 1th_day/leaflet_burden_hbp_whd2013.pdf.

3. American Heart Association. High Blood Pressure. $\quad 2013$. http://www.heart.org/idc/groups/heartpublic/@wcm/@sop/@smd/documents/do wnloadable/ucm_319587.pdf

4. Kementerian Kesehatan RI. Hasil Riset Kesehatan Dasar. Badan Penelitian dan Pengembangan Kesehatan; 2013.

5. Yoon P, Gillespie C, George M, Wkly HW-MMM, 2012 U. Control of hypertension among adults-National Health and Nutrition Examination Survey, United States, 2005-2008.

6. Nwankwo T, Yoon S, Burt V. Hypertension among adults in the United States: national health and nutrition examination survey, 2011-2012. Published online 2013.

7. Singh S, Shankar R, Hypertension GS-I journal of, 2017 U. Prevalence and 
associated risk factors of hypertension: a cross-sectional study in urban Varanasi.

8. Dinas Kesehatan Provinsi Sulawesi Tengah. In: ; 2016.

9. Dinas Kesehatan Provinsi Sulawesi Tengah. Data Faktor Resiko Penyakit Tidak Menular Di Stulawesi Tengah.; 2016.

10. Puskesmas Bulili. Data 10 Penyakit Terbesar Di Puskesmas Bulili Palu.; 2017.

11. Centers for Disease Control and Prevention, (CDC). Division for Heart Disease and Stroke Prevention. High Blood Pressure Fact Sheet.; 2016.

12. Jamal A, Elye P, S. Gentzke A, et al. Current Cigarette Smoking Among Adults - United States, 2016. MMWR Morb Mortal Wkly Rep. 2018;67(2):53-59. doi:10.15585/MMWR.MM6702A1

13. Asma S, Mackay J, Song SY, et al. Global Tobacco Surveillance System: The GATS Atlas.; 2015.

14. Heart Foundation. Blood Pressure. National Heart Foundation of Australia (national office). Published 2013. http://www.heartfoundation.org.au/SiteCol lectionDocument/NAHU-Bloodpressure.pdf

15. American Collage of Cardiology and American Heart Association. Guideline for the Prevention, Detection, Evaluation and Management of High Blood Pressure in Adults.; 2017.

16. Hadi MC. Karakteristik Perokok Di Indonesia (Kajian Terhadap Hasil Riskesdas 2007 - 2010). J Skala Husada. 2013;10(1):1-6.

17. Untario E. Hubungan Merokok Dengan Kejadian Hipertensi. Keperawatan. 2017;11(11):40-47.

18. Saputra AI. Profil Gaya Hidup Dan Tekanan Darah Penduduk Dewasa Di Wilayah Kerja Puskesmas Tipo Palu Tahun 2018. 2018;5(1):65-71.

19. Anggraeny, Rini dkk. Puskesmas Pattingalloang Kota Makassar Risk Factor of Physical Activity, Smoking, and Alcohol Consumption on the Incidence of Hypertention in Elderly in The Region of
Bagian Epidemiologi FakultasKesehatan Masyarakat Universitas Hasanuddin 2013. Published online 2013.

20. Wahyudi AI. Gambaran Tekanan Darah Berdasarkan Faktor Pemberat Hipertensi pada Pasien Hipertensi Perokok di Wilayah Kerja Puskesmas Ciputat Kota Tangerang Selatan. Published online 2014.

21. K. ANT. Hubungan Antara Kebiasaan Merokok Dengan Tekanan Darah Meningkat Karyawan Laki-Laki Di Nasmoco Semarang. J Kesehat Masy Univ Diponegoro. 2012;1(2):18783.

22. Mannan H, Wahiduddin, Rismayanti. Faktor Risiko Kejadian Hipertensi di Wilayah Kerja Puskesmas Bangkala Kabupaten Jeneponto Tahun 2012. Fak Kesehat Masy Univ Hasanuddin. Published online 2012:1-13.

23. Saraswati I, Rachmadi D. Hipertensi dan obesitas pada anak. Published online 2010:1-14.

24. Adnyani PP, Sudhana IW. Prevalensi Dan Faktor Risiko Terjadinya Hipertensi Pada Masyarakat Di Desa Sidemen, Kecamatan Sidemen, Karangasem Periode Juni-Juli 2014. E-Jurnal Med Udayana. Published online 2014:1-16.

25. Sugiharto A. Faktor-Faktor Risiko Hipertensi Grade II Pada Masyarakat (Studi Kasus di Kabupaten Karanganyar).

26. Shapo L, Pomerleau J, McKee M. Epidemiology of hypertension and associated cardiovascular risk factors in a country in transition: A population based survey in Tirana City, Albania. $J$ Epidemiol Community Health. 2003;57(9):734-739. doi:10.1136/jech.57.9.734

27. Nuraini B. Risk Factors of Hypertension. $J$ Major. 2015;4(5):10-19.

28. Rahajeng E, Tuminah S. Prevalensi Hipertensi dan Determinannya di Indonesia. Maj Kedokt Indones. 2009;59:580-587.

29. Tirtasari S, Kodim N. Prevalensi dan Karakteristik Hipertensi Pada Usia Dewasa Muda di Indonesia. Tarumanagara Med J. 2019;1(2):395-402 